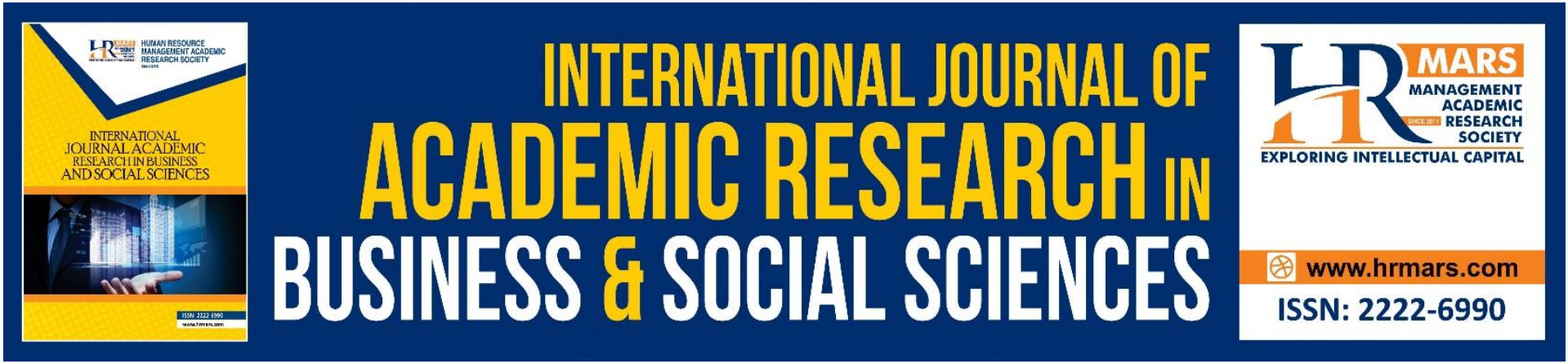

\title{
A Review Paper on Acceptance of Students with Disabilities among Non-Disabled Students in The Higher Education Institution
}

Nur Ain Nabisya Azmi, Wan Arnidawati Wan Abdullah \& Asmidawati Ashari

To Link this Article: http://dx.doi.org/10.6007/IJARBSS/v11-i11/11776

DOI:10.6007/IJARBSS/v11-i11/11776

Received: 11 September 2021, Revised: 14 October 2021, Accepted: 29 October 2021

Published Online: 19 November 2021

In-Text Citation: (Azmi et al., 2021)

To Cite this Article: Azmi, N. A. N., Abdullah, W. A. W., \& Ashari, A. (2021). A Review Paper on Acceptance of Students with Disabilities among Non-Disabled Students in The Higher Education Institution. International Journal of Academic Research in Business and Social Sciences, 11(11), 2572 - 2582.

Copyright: (c) 2021 The Author(s)

Published by Human Resource Management Academic Research Society (www.hrmars.com)

This article is published under the Creative Commons Attribution (CC BY 4.0) license. Anyone may reproduce, distribute, translate and create derivative works of this article (for both commercial and non0-commercial purposes), subject to full attribution to the original publication and authors. The full terms of this license may be seen at: http://creativecommons.org/licences/by/4.0/legalcode

Vol. 11, No. 11, 2021, Pg. $2572-2582$

Full Terms \& Conditions of access and use can be found at http://hrmars.com/index.php/pages/detail/publication-ethics 


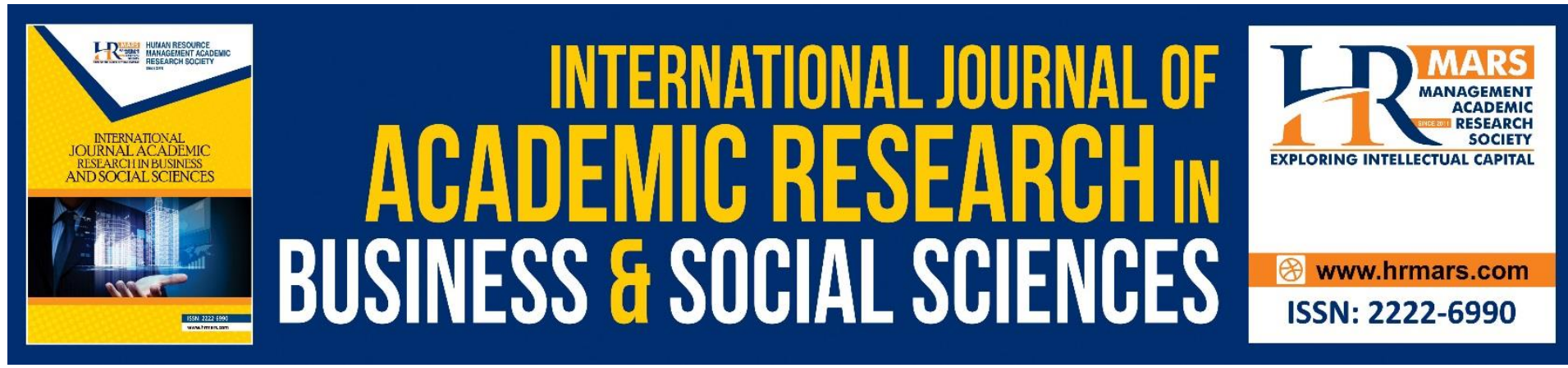

\title{
A Review Paper on Acceptance of Students with Disabilities among Non-Disabled Students in The Higher Education Institution
}

\author{
Nur Ain Nabisya Azmi, Wan Arnidawati Wan Abdullah \& \\ Asmidawati Ashari \\ Department of Human Development and Family Studies, Faculty of Human Ecology, \\ Universiti Putra Malaysia \\ Email: arnidawati@upm.edu.my
}

\begin{abstract}
The current conceptual paper focuses on students with disabilities in higher education, where the inclusive education initiative has paved the way for them to further their education. Higher education institutions, on the other hand, have a different environment than schools, and it takes more effort for them to adjust and fit in with their non-disabled peers. Thus, the purpose of this paper is to provide a general understanding of students with disabilities in higher education, including definitions of students with disabilities, policies, theories, and issues related to their acceptance among non-disabled students. Positive acceptance from peers is expected to help students with disabilities improve their self-esteem, academic performance, and mental health. The internal and external reinforcers of acceptance, which explain the influence of inner qualities and environmental factors surrounding a person in developing acceptance, are among the key issues discussed in the paper. A positive attitude toward students with disabilities can be anticipated by identifying the factors. As a result, a welcoming environment for students with disabilities to pursue higher education can be created.
\end{abstract}

Keywords: People with Disabilities, Acceptance, Higher Education, Inclusive Campus, Inclusive Education

\section{Introduction}

Persons with disabilities (PWDs) face new challenges every day as they adjust to and cope with their lives. The most common and unavoidable challenge for them is mistreatment in every aspect of their lives, ie in the community, education or workplace (Toran et al., 2009; Alias et al., 2016; Abdullah, 2020). People frequently misinterpret them as charitable figures due to the negative stigma associated with constantly seeking financial assistance. Despite being provided with a list of advantages, implementation is not as smooth as it should be. They are frequently subjected to discrimination or are denied their right to receive the benefit. A non-disabled person, for example, may park their car in an accessible parking space, making it difficult for PWDs to park. 
Their difficulties extend beyond their daily lives to their education. Education is as crucial for PWDs as it is for non-disabled people to ensure a better future. Through the current implementation of inclusive education, PWDs now have a more incredible opportunity in schools. More parents are enrolling their children in schools, including both public and private schools. It demonstrates that more people are becoming aware of the potential of education to improve the quality of life for PWDs.

Nowadays, students with disabilities (SWDs) who excel academically have a better chance of continuing their education at a higher level. The Ministry of Higher Education (MoHE) of Malaysia reported that approximately 2444 SWDs enrolled in Malaysian public universities in 2017 (Mustaffa et al., 2019).

\section{Persons with Disabilities (PWDs): Definition and Types of disabilities}

The American Disabilities Act 2018(ADA) defines a person with a disability as having a physical or mental impairment that significantly limits one or more major life activities, and it also includes those who have a record of such impairment, even if they do not currently have any disability (ADA National Network, 2018). Persons with disabilities, as defined by the Persons with Disabilities Act of 2008, have a long-term or permanent physical, mental, intellectual, or sensory impairment. These impairments prevent them from participating fully or effectively in society. According to the Department of Social Welfare Malaysia, seven types of disabilities are considered: hearing, sight, speech, physical, learning difficulties, mental health, and multiple disabilities (see Figure 1).

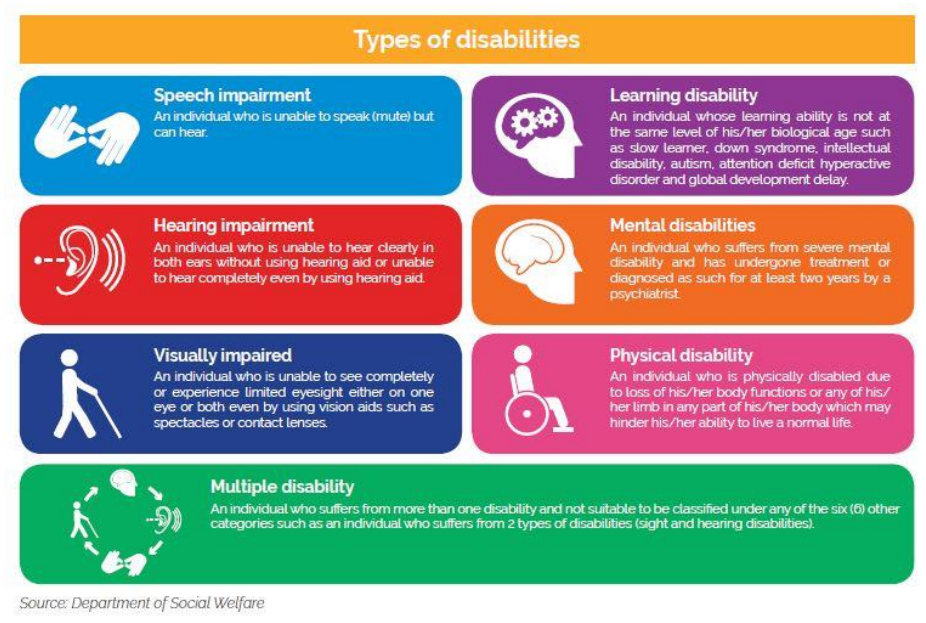

Figure 1 Types of disabilities

According to the Department of Social Welfare, there were 588,159 registered people with disabilities as of December 2020. Physical disabilities and learning disabilities are the two most common types of disabilities when compared to other types of disabilities (See Figure 2). However, because registration is voluntary, accurate records of Malaysia's disabled population are unknown. 


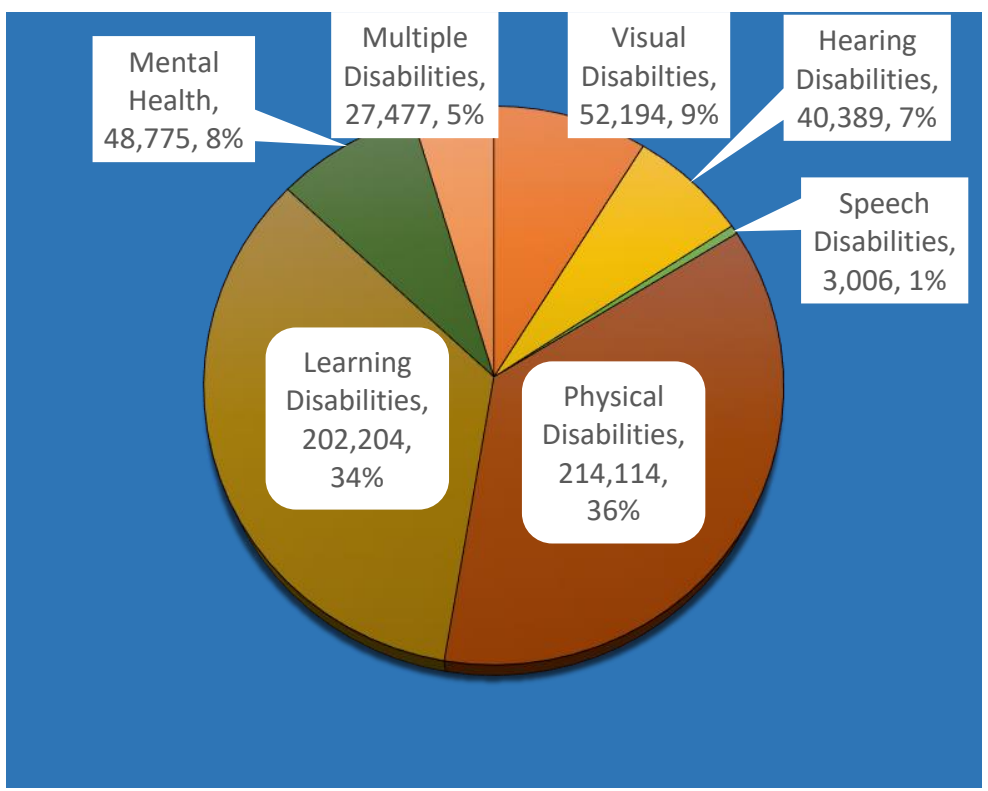

Source: Department of Social Welfare, Malaysia

Figure 2 Registration according to types of impairment as of December 2020

\section{Policy Related to Disability in Malaysia}

The United Nations Convention on the Rights of Persons with Disabilities (UNCRPD), which entered into force in 2008, recognises and acknowledges the rights of PWDs. Beforehand, there are a few instruments in place to protect the rights of PWD, such as the Declaration on the Rights of Disabled Persons (1995), the World Programme of Action Concerning Disabled Persons (1981), the Principles for the Protection of Persons with Mental Illness and the Improvement of Mental Health Care (1991), and the Standard Rules on the Equalisation of Opportunities for Persons with Disabilities (1991). The UNCRPD certifies that those rights have been secured, ensured, and protected following the convention's provisions. It promotes disabled communities to fully participate in society to be treated as full members of society. According to the European Union Agency for Fundamental Rights (FRA), this convention has been ratified by 182 countries and signed by 164 countries. Malaysia ratified the UNCRPD on July 19, 2010, indicating its willingness to act on the rights of people with disabilities in Malaysia.

The growing global awareness of the importance of disability-inclusive development is currently changing the development trend. The disabled community is one of seven target groups in the planned development of the Sustainable Development Goals (SDG). Furthermore, the 2030 Agenda for Sustainable Development stated that disability should not be a barrier to obtaining one's rights, nor should a lack of access to development programming impediment obtaining one's rights (Worldbank, 2018). Meanwhile, changes may be seen in Malaysia that the government prioritises equal rights, as outlined in the Disabilities Act of 2008 and being the signatory of the UNCRPD. A strategic plan focusing on the development of disabled people was also drafted through the Action Plan for Persons with Disabilities 2016-2022. As a result, Malaysia began to fully integrate disabled people into society and the country's development. Subsequently, the definition of people with disabilities also has shifted from a welfare to a human rights perspective (Unicef Malaysia, 2018). 
Malaysia has taken a step forward on this issue, and gradually improving the efficiency of the existing Zero Reject Policy beginning in 2019 to ensure that children with special needs are not excluded from education. This policy ensures that children with special needs are enrolled in the mainstream school through the Special Integration Education Program (Program Pendidikan Khas Integrasi) or the Inclusive Education Program (Program Pendidikan Inklusif), or in the Special Education School (Sekolah Pendidikan Khas) (Pressreader, 2019). This policy implementation provides a new opportunity for Malaysian children with special needs to seize opportunities to build a better future. Education can help them become self-sufficient members of society and improve their quality of life. However, in high education institutions, students with disabilities (SWDs) are not separated into different programmes based on their needs but instead participate alongside non-disabled students in an inclusive setting.

As the number of students with disabilities enrolling in public universities grows, steps are taken to ensure that they are accepted and do not lose their chances of furthering their education. However, some universities refuse to accept disabled students due to a lack of facilities and accommodations. Dr Ruzita Mohd Amin, Economy Professor and Head of Disability Services Unit (DSU) at International Islamic University of Malaysia (IIUM), stated that the government had issued a Guideline for Implementing Disability-Inclusive Policy in Higher Education Institutions in order to resolve the issue. Starting with the 2019/2020 student enrollment session, all 20 local universities must implement a disability-inclusive policy and establish a disability service unit following this guideline (Bernama, 2019). This initiative is expected to assist SWDs' adjustment and improve their learning experiences in higher education. The Disability Service Unit, in particular, seeks to meet the needs of SWDs in higher education while also protecting their rights and well-being.

\section{SWDs in Higher Education Institutions}

According to the Malaysian Education Act, 1996 in (Special Education) Regulations 2013, students with disabilities are those who are certified by a medical practitioner, an optometrist, an audiologist or a psychologist, as the case may be, regardless of being in service of a government or not, as a student having the following condition(s); (1) Visual disability; (2) Hearing disability; (3) Speech disability; (4) Physical disability; (5) Learning difficulties; or (6) Any combinations of disabilities (Alias et al., Ibrahim 2016). Due to functional limitations, students with special needs require assistance or guidance to enhance their learning experience in educational settings. Under a sub-article of the Universal Declaration of Human Right, it was stated that free and compulsory education, at least at the elementary level, is subjected to everyone. It is a right that everyone deserves, and other types of education such as vocational and professional education must be generally available and equal access to higher education based on merit (Nasir \& Efendi, 2017).

Students with disabilities (SWDs) in higher education institutions (HEI), as opposed to students with disabilities in primary and secondary school, require more advanced assistance because they must manage themselves independently. According to Hong (2015), transitioning from high school to $\mathrm{HEl}$ can be difficult for students in general, let alone SWDs. This level of complexity necessitates assistance with transportation, learning processes (taking notes, sitting for exams, completing assignments), access to toilets, lecture rooms, exam halls, and a suitable residence to live in for the semester. However, the extent of these accommodations may differ depending on the type and severity of a disability. A student with 
a hearing impairment, for example, may not need transportation assistance because he can use public transportation with non-disabled students, but a student in a wheelchair does. Berggren et al (2016) compared the experiences of high school students with disabilities in Sweden, the Czech Republic, and the United States. According to the study, invisible disabilities, such as mental disabilities, are challenging to manage because they are not visible. Students with mental disabilities, for example, may require additional time in exams, and tolerance from lecturers or faculty members may be beneficial.

Furthermore, providing accommodation for these students can be challenging. It is undeniable that leading an independent life can be difficult for SWDs, particularly when it comes to finding accommodations. Although it is the student's responsibility to notify lecturers and staff about their disability accommodations, they may not receive them as soon as they would like. Besides, disclosing a disability does not always result in successful accommodation because faculty members may reject it.

SWDs would be perplexed in some cases if staff members' roles in dealing with SWDs were unclear (Berggren et al., 2016). When students approach lecturers for help, they are often turned down because it is not their responsibility to help. SWDs had to be brave to disclose their disabilities, and rejection can cause them to hide even more. SWDs work hard to maintain their normal identities, to the point where they would not reveal their disability unless they were experiencing severe difficulties. Their learning experience can be improved if they receive proper assistance. Students with visual disabilities, for example, may require a helper to copy down notes and explain the course to them in detail. Wheelchair users, on the other hand, may require specialised transportation as they cannot use public transport on their own. Meanwhile, students with learning disabilities may require additional time or separate locations to complete tests, depending on their mental state (Berggren et al., 2016).

Ziswiler (2014) agreed that higher education is mainly unstructured and unsupervised compared to secondary school. Therefore, SWDs will have to juggle between adapting to transition from secondary education and being independent enough to manage themselves to self-advocate their disabilities. Higher education institutions give exposure in various areas such as time management, independence, and in short, the balance of both academic and non-academic activities. Having disabilities may make the experience to be more complicated than it already is. Transitioning to higher education causes some of the SWDs to face problems in achieving success according to the standard of normalcy and building relationships with faculty members and peers (Meyer, 2012). At times, social isolation is unavoidable for SWDs because of the difference in lifestyles. For example, they might need more time to revise than their peers and are forced to pass off social activities (Meyer, 2012). Meyer (2012) further added that SWDs choose to hide their disabilities and not use disabilities support services because they are aware of their cultural stigmas, giving them a fear of rejection, being judged or excluded by their peers. SWDs indicated that being associated with any disabilities service support or being seen walking into the Disability Services Unit would result in a negative perception. The negative perception triggers avoidance behaviour causing SWDs to hide their disabilities more. However, by concealing their disabilities, they are losing the opportunities to receive the accommodations they deserved. 


\section{Acceptance of SWDs among non-SWDs in Higher Education}

According to the Cambridge dictionary, acceptance means agreeing to something, such as an offer or invitation. Acceptance, on the other hand, is a broad concept that varies depending on the situation. It refers to a person's expression of approval to the reality of a situation, recognising a process or condition without making any changes. According to Williams and Lynn (2010), acceptance has four meanings: 1) taking or receiving something as a pleasure, satisfaction of a claim, or a duty; 2) favourable reception, regard, or approval; 3) assenting to or believing; and 4) acceptability (Brown, 1993; Merriam-Webster, 1993; Weiner \& Simpson). Furthermore, there are two types of acceptance: self-acceptance and acceptance of others, which focus on being aware of the good and bad sides of oneself and others while maintaining a positive attitude (Williams \& Lynn, 2010). Acceptance will always exist, whether in primary, secondary, or higher education or even in the workplace. Acceptance, on the other hand, is difficult to achieve, primarily when society has formed a firm mental schema on what disability looks like, mostly negatively.

Acceptance can be reinforced by whether internal or external factors. This concept of reinforcement comes from the theory of Operant Conditioning by B.F Skinner. His theory involves a type of learning where an individual's behaviour is reinforced or punished. The desired behaviour is expected to be repeated when reinforced and avoided when being punished. Intuitively, people tend to repeat rewarded actions and avoid punishment (GradesFixer, 2018). Therefore, this type of learning can be used to generate the desired behaviour.

Internal reinforcer means that the reinforcement comes from the inside of an individual, without gaining any external reward or stimulated by external cues (Powell, 2012). Contrary to the external reinforcer, internal reinforcer comes from one's internal value, morals and aesthetics (Alexander, 2011). In the current study, internal reinforcer refers to the internal factors surrounding non-disabled students and how it influences their acceptance towards Students with Disabilities (SWDs). This acceptance includes what kind of information that non-disabled students personally have on disability generally and social interaction between them and SWDs.

Examples of internal reinforcers include personal knowledge and personal contact with SWDs. Knowledge is necessary because it influences one's decision making and will result in behaviour. On the other hand, contact with SWDs in this study refers to how interactions occur between SWDs and non-disabled students associated in various settings such as acquaintances, group members, and study partners. Shamsudin (2002) mentioned that it is difficult for an individual to decide and act positively on an issue (Tanbi \& Hazan, 2017). According to Toran et al., 2010, knowledge may be one of the crucial keys to change negative attitudes towards persons with disabilities and knowing disability will lead to less negative stereotypes, resulting in a more positive attitude towards persons with disabilities. Besides, knowledge and prior engagement between SWDs and non-disabled students positively correlate to a positive attitude towards persons with disabilities (Fatt \& Rasid, 2017). Fatt and Rasid (2017) further added that positive attitudes from the public could be further extended by providing more exposure to knowledge and experiences with PWDs. 
In contrast, external reinforcer means that the reinforcement comes from the outside surroundings of an individual. The external reinforcer is the extent to which a person estimates that their behaviour resulted from either chance, luck, or fate, and it comes from other people in power, not themselves (Rotter, 1990). In this study, external reinforcer refers to the environmental factors surrounding non-disabled students and their acceptance of SWDs. This environment includes the class environment, family environment, and social environment. An example of an external reinforcer is social influence. Social influence can be defined as efforts or means done to change other's beliefs, attitudes or behaviours, intentionally or unintentionally (International Encyclopedia of the Social \& Behavioral Sciences, 2015). It refers to the idea where an individual changes the way they are behaving or thinking to meet the demands of a social group, especially when the perceived authority is high. There are two types of social influence, which are informative and normative. Informative social influence happens when people feel they lack knowledge or information and turn to others to affirm the needed information.

Meanwhile, normative social influence happens when people want to be accepted, respected, and fit in a social group to adjust their behaviours or thoughts according to the majority. Social influence refers to peoples' role around non-disabled students, including their peers, family, lecturers and media, in enhancing acceptance towards SWDs. Prejudice against SWDs is challenging to change in higher education because non-disabled do not experience what SWDs do. Therefore, they cannot comprehend the situation, leading them to act up (Tanbi \& Hazan, 2017). Acceptance of SWDs, on the other hand, is not always negative. There are instances where SWDs are positively accepted. Baker, Boland \& Nowik (2012) discovered that both faculty and students agreed that the environment welcomes SWDs. Even though SWDs were hesitant to disclose their disabilities to faculty members, their ability to achieve an excellent academic result was not denied. Regardless of the student's disability, faculty members are trying their best to assist the student. According to Toran and Muhamad (2010), non-disabled students have a positive attitude and acceptance of SWDs. They did not believe that having a friend with a disability would interfere with their studies, and they were reluctant to be involved with SWDs. They also advocate the rights of persons with disabilities to equal educational opportunities and fair treatment as non-disabled people. This action demonstrates positive acceptance of SWDs.

Acceptance by peers as being treated relatively despite disabilities is critical for SWDs because they rely heavily on their peers throughout their learning journey Hasnah et al (2009) conducted a study to identify the supports and challenges people with disabilities face. The majority of respondents valued social support from their peers. The study demonstrated how positive peer acceptance could significantly improve the well-being of SWDs on campus. SWDs expressed gratitude to their peers who assisted them during and outside lectures, campus activities, and group activities. It was claimed that the absence of their peers made it difficult for them to actively participate in group activities. They struggled to keep up with the fast-talking group members, making it challenging to translate the discussion content. They are frequently excluded from activities because they believe they will struggle or fail to complete tasks efficiently.

SWDs are naturally concerned with how others perceive them. Therefore, acceptance in a challenging environment is critical for SWDs, particularly among their peers. Because the 
negative stigma of their peers hampers them, rejection of others can cause mental and emotional harm (Margalit et al., 2002). This insecurity may impair their ability to perform well academically and socially. Acceptance of others, on the other hand, improves PWDs' socialisation experiences, life independence, and quality of life (Reddy \& Sukathamalini, 2006; Columna et al., 2009). As a result, non-disabled students should be encouraged to understand and embrace the differences among SWDs through disability awareness in the form of acceptance. This understanding should lead to good synergy and collaboration between these two groups. For the past few years, public awareness on disability-related issues has been a never-ending debate, and university students were assumed to have little information about disability awareness (Azizi et al., 2018).

Meanwhile, inclusive education has paved the way for SWDs to improve their quality of life by encouraging the empowerment of knowledge, skills, and job acquisition as a means of achieving independence (Morgado et al., 2016). In an ideal world, the policy would depict a welcoming environment for SWDs at higher education institutions. In reality, however, SWDs are not receiving what they should. They have difficulty adapting to, fitting in with, and keeping up with the rest of the community. They find it difficult to actively participate in group activities due to negative perceptions that SWDs burden the group or are incapable of completing a task (Toran, 2009). Acceptance of SWDs among non-disabled students will improve their experience and well-being in higher education.

\section{Theories on Acceptance}

Two significant theories can be used to explain the acceptance of SWDs. First, acceptance is a type of attitude that can be reinforced to produce desired results. According to Allport (1954), the interaction between two groups can help in the reduction of prejudice and the promotion of tolerance. Allport's Theory of Intergroup Contact discusses the beneficial effects of intergroup contact on reducing negative prejudice and increasing positive acceptance. Allport's theory has seen widespread application in the field of inclusive education. The majority of studies show that social interaction leads to positive acceptance. As a result, this theory is deemed appropriate for elaborating on the potential acceptance of SWDs in higher education. This theory proposes that interaction between SWDs and non-SWDs in higher education would result in mutual and positive acceptance. The interaction will likely occur, and it is unavoidable while completing tasks and assignments.

The second is Albert Bandura's Social Cognitive Learning Theory. Bandura acknowledged classical and operant conditioning theory but added two ideas: 1) a mediating process occurs between stimuli and responses, and 2) behaviour is learned from the environment through observation and modelling. Nabavi (2011-2012) stated the basic assumptions of this theory, which are 1) people can learn by observing others, 2) learning is an internal process that may or may not result in behaviour change, and 3 ) learning can occur without a behaviour change, as in observation without imitation. Learning is a vital component of this theory, as humans are believed to learn by interacting with one another and their environment. Acceptance of SWDs in higher education can thus be generated by modelling and observing positive behaviour toward SWDs. Personal experiences and the social influence of others are critical in encouraging non-disabled students' cheerful acceptance of SWDs. Because humans are said to learn from the behaviour of others, non-disabled students should develop a positive 
acceptance of SWDs if they have good exposure to SWDs from their external environments, such as lecturers, faculty members, or parents.

\section{Conclusion}

As the number of SWD enrolled in public universities grows, steps should be taken to promote positive acceptance and recognise their educational opportunities. Further research on the level of acceptance of SWDs among their non-disabled peers as well as understanding the factors of acceptance, should be expected to contribute to improving inclusive education implementation by raising campus community awareness of the issue. As positive acceptance grows, enrollment rates among SWDs are likely to rise. Therefore, staff and stakeholders can plan appropriate action to spread and increase acceptance among students.

Acceptance of SWDs in higher education, in a nutshell, is critical for their development and well-being throughout their learning journey. Given adequate support and resources, SWDs can perform well academically and socially, just like their non-disabled peers. Positive acceptance will also create a harmonious environment in which SWDs and non-SWDs can coexist. Differences should not keep them apart but rather bring them closer together in peace. Current research is critical in preparing a welcoming and conducive environment for SWDs to pursue their education and build a better future.

\section{References}

Alias, R., Alias, N. A., \& Ibrahim, A. B. (2016). Towards inclusive education in Malaysian Universities: addressing the barriers, challenges and needs of special educational needs learners. In 7th International Conference on University Learning and Teaching (InCULT 2014) Proceedings (pp. 409-421). Springer, Singapore.

Azizi, N. A. A., Rabun, M. N., \& Badarin, N. A. S. (2018). Are we disabled among the disabled? disability awareness among university of malaya students. Journal of Administrative Science, 15(1). ADA National Network (ADA), 2018.

Bernama. (2017). 443,541 disabled persons registered with welfare department as of October 2017: Azizah. The Sun Daily. Retrieved from https://www.thesundaily.my/archive/443541-disabled-persons-registered-welfaredepartment-october-2017-azizah-KUARCH505292

Hong, B. S. S. (2015). Qualitative Analysis of the Barriers College Students with Disabilities Experience in Higher Education. Journal of College Student Development, 56(3), 209226.doi:10.1353/csd.2015.0032.

Berggren, J. U., Rowan, D., Bergbäck, E., \& Blomberg, B. (2016). Disabled students' experiences of higher education in Sweden, the Czech Republic, and the United Statesa comparative institutional analysis. Disability \& Society, 31(3), 339-356.

Meyer, R. H. (2012). College students with disabilities' motivation to utilize disability support services: A qualitative investigation. Temple University.

Morgado, B., Cortés-Vega, M. D., López-Gavira, R., Álvarez, E., \& Moriña, A. (2016). Inclusive education in higher education?. Journal of Research in Special Educational Needs, 16, 639-642.

Nasir, M. N. A., \& Efendi, A. N. A. E. (2017). Special education for children with disabilities in Malaysia: Progress and obstacles Muhamad Nadhir Abdul Nasir. Geografia-Malaysian Journal of Society and Space, 12(10).

Official Portal of Department of Social Welfare Malaysia. (n.d.). Retrieved from https://www.jkm.gov.my/jkm/index.php 
Powell, A., \& Smith, M. (2012). Positive Reinforcers Extrinsic \& Intrinsic [PowerPoint slides]. Prezi. Retrieved from https://prezi.com/jpqoc95_a-19/positive-reinforcers-extrinsicintrinsic/ .

Reddy, G. L., \& Sujathamalini, J. (2010). Children with disabilities: Awareness, attitude and competencies of teachers. Discovery Publishing House.

Sniatecki, J., Perry, H., \& Snell, L. (2015). Faculty attitudes and knowledge regarding college students with disabilities. Journal of Postsecondary Education and Disability.

Toran, H., Yasin, M. H. M., Tahar, M. M., \& Sujak, N. (2009). Sokongan dan halangan yang dihadapi pelajar-pelajar kurang upaya di sebuah institusi pengajian tinggi di Malaysia. Asean Journal of Teaching and Learning in Higher Education, 1(2), 18-29.

Toran, H. (2010). Pengetahuan dan sikap rakan sebaya terhadap pelajar kurang upaya di sebuah IPTA di Malaysia. Asean Journal of Teaching and Learning in Higher Education (AJTLHE), 2(2), 21-32.

Tambi, N., \& Hazan, N. A. N. (2017). Hubungan Antara Pengetahuan Dan Sikap Mahasiswa Universiti Kebangsaan Malaysia Terhadap Golongan Orang Kurang Upaya (Relationship between Knowledge and Attitude of Students towards People with Disabilities in Universiti Kebangsaan Malaysia). e-Bangi, 14(5).

United Nations. (n.d). Frequently Asked Questions regarding the Convention on the Rights of Persons with Disabilities. Retrieved from https://www.un.org/development/desa/disabilities/convention-on-the-rights-ofpersons-with-disabilities/frequently-asked-questions-regarding-the-convention-onthe-rights-of-persons-with-disabilities.html

UNICEF Malaysia. (2018). Follow-up Survey on Knowledge, Attitudes, Practices towards Inclusion of Children with Disabilities. Retrieved from https://www.unicef.org/northmacedonia/media/3181/file/MK_2018_DisabilityKapRe port_ENG.pdf

Abdullah, W. (2020). Experience in Employment and Meaning of Independent Living among Adults with Learning Difficulties. International Journal for Studies on Children, Women, Elderly And Disabled, 9, 47-54.

Williams, J. C., \& Lynn, S. J. (2010). Acceptance: An historical and conceptual review. Imagination, cognition and personality, 30(1), 5-56.

The World Bank. (2018, September 26). Disability Inclusion. Retrieved from https://www.worldbank.org/en/topic/disability

Ziswiler, K. M. (2014). Predicting student engagement by disability type at four-year baccalaureate higher education institutions using self-reported data (Doctoral dissertation, University of Dayton). 